\title{
Stimulation of Suicidal Erythrocyte Death by the Antimalarial Drug Mefloquine
}

\author{
Rosi Bissinger Susanne Barking Kousi Alzoubi Guilai Liu Guoxing Liu \\ Florian Lang \\ Department of Physiology, University of Tübingen, Germany
}

\section{Key Words}

Phosphatidylserine $\cdot$ Calcium $\bullet$ Cell volume $\bullet$ ROS $•$ Oxidative stress $\bullet$ Eryptosis $•$ Malaria

\begin{abstract}
Background: The antimalarial drug mefloquine has previously been shown to stimulate apoptosis of nucleated cells. Similar to apoptosis, erythrocytes may enter suicidal death or eryptosis, which is characterized by cell shrinkage and phospholipid scrambling of the erythrocyte cell membrane with phosphatidylserine translocation to the erythrocyte surface. Stimulators of eryptosis include oxidative stress, increase of cytosolic $\mathrm{Ca}^{2+}$-activity $\left(\left[\mathrm{Ca}^{2+}\right]_{\mathrm{i}}\right)$, and ceramide. Methods: Phosphatidylserine abundance at the cell surface was estimated from annexin $\mathrm{V}$ binding, cell volume from forward scatter, reactive oxidant species (ROS) from $2^{\prime}, 7^{\prime}$-dichlorodihydrofluorescein diacetate (DCFDA) fluorescence, $\left[\mathrm{Ca}^{2+}\right]_{i}$ from Fluo3fluorescence, and ceramide abundance from specific antibody binding. Results: A $48 \mathrm{~h}$ treatment of human erythrocytes with mefloquine significantly increased the percentage of annexin-V-binding cells $(\geq 5 \mu \mathrm{g} / \mathrm{ml})$, significantly decreased forward scatter $(\geq 5 \mu \mathrm{g} / \mathrm{ml})$, significantly increased ROS abundance $(5 \mu \mathrm{g} / \mathrm{ml})$, significantly increased $\left[\mathrm{Ca}^{2+}\right]_{\mathrm{i}}(7.5 \mu \mathrm{g} / \mathrm{ml})$ and significantly increased ceramide abundance $(10 \mu \mathrm{g} / \mathrm{ml})$. The up-regulation of annexin$\mathrm{V}$-binding following mefloquine treatment was significantly blunted but not abolished by removal of extracellular $\mathrm{Ca}^{2+}$. Even in the absence of extracellular $\mathrm{Ca}^{2+}$, mefloquine significantly increased annexin-V-binding. Conclusions: Mefloquine treatment leads to erythrocyte shrinkage and erythrocyte membrane scrambling, effects at least partially due to induction of oxidative stress, increase of $\left[\mathrm{Ca}^{2+}\right]_{i}$ and up-regulation of ceramide abundance.
\end{abstract}

Copyright (C) 2015 S. Karger AG, Basel

\section{Introduction}

Mefloquine has been used for the chemoprophylaxis and treatment of malaria [1-8], schistosomes and other helminthes [9]. The use is limited by various side effects [4] including neuropsychiatric disorders [10-14], skin reactions [15] as well as risk of miscarriage and

Prof. Dr. Florian Lang

KARGER 125
Physiologisches Institut der Universität Tübingen

Gmelinstr. 5, D-72076 Tübingen (Germany)

Tel. +49 707129 72194, Fax +49 707129 5618, E-Mail florian.lang@uni-tuebingen.de 
stillbirth [16]. Mefloquine triggers apoptosis [17-21] and may sensitize tumor cells for cytostatic treatment [20]. Mechanisms involved in mefloquine induced apoptosis include oxidative stress $[10,18,21]$, ceramide formation [22] and caspase activation $[14,18]$.

The clinical course of malaria could be favourably influenced by drugs stimulating suicidal erythrocyte death or eryptosis [23], which, similar to apoptosis, is characterized by cell shrinkage [24] and translocation of phosphatidylserine from the cell interior to the erythrocyte surface [25]. Stimulators of eryptosis include oxidative stress [25], increased cytosolic $\mathrm{Ca}^{2+}$ activity ([Ca $\left.{ }^{2+}\right]_{\mathrm{i}}$ ), ceramide [26], energy depletion [25], and activated caspases $[25,27,28]$. Moreover, eryptosis is triggered by activated casein kinase $1 \alpha$, Janus-activated kinase JAK3, protein kinase C, p38 kinase, and PAK2 kinase [25], as well as by inhibited or lacking AMP activated kinase AMPK, cGMP-dependent protein kinase, sorafenib sensitive kinases and sunitinib sensitive kinases [25]. Stimulators of eryptosis further include diverse xenobiotics [25, 29-57].

Eryptotic phosphatidylserine exposing erythrocytes are engulfed by macrophages and thus rapidly cleared from circulating blood [25]. Accordingly, excessive eryptosis may lead to anemia, if the removal of eryptotic erythrocytes exceeds the formation of new erythrocytes [25]. Phosphatidylserine exposing erythrocytes may further bind to endothelial CXCL16/ SR-PSO with adherence to the vascular wall [58]. They may further trigger blood clotting and thrombosis [59-61]. Thus, phosphatidylserine exposing erythrocytes may impair microcirculation $[26,59,62-65]$.

The present study tested, whether and how mefloquine may trigger eryptosis. To this end, erythrocytes from healthy volunteers were incubated with or without mefloquine and phosphatidylserine and ceramide abundance at the erythrocyte surface, cell volume, reactive oxidant species and $\left[\mathrm{Ca}^{2+}\right]_{\mathrm{i}}$ determined utilizing flow cytometry.

\section{Materials and Methods}

\section{Erythrocytes, solutions and chemicals}

Fresh Li-Heparin-anticoagulated blood samples were kindly provided by the blood bank of the University of Tübingen. The study is approved by the ethics committee of the University of Tübingen (184/2003 V). The blood was centrifuged at $120 \mathrm{~g}$ for $20 \mathrm{~min}$ at $23{ }^{\circ} \mathrm{C}$ and the platelets and leukocytes-containing supernatant was disposed. Erythrocytes were incubated in vitro for 48 hours at a hematocrit of $0.4 \%$ in Ringer solution containing (in $\mathrm{mM}$ ) $125 \mathrm{NaCl}, 5 \mathrm{KCl}, 1 \mathrm{MgSO}_{4^{\prime}} 32 \mathrm{~N}$-2-hydroxyethylpiperazine-N-2-ethanesulfonic acid (HEPES), 5 glucose, and $1 \mathrm{CaCl}_{2}$; the $\mathrm{pH}$ was adjusted to 7.4 and the temperature kept at $37^{\circ} \mathrm{C}$. Where indicated, erythrocytes were exposed to mefloquine (Sigma Aldrich, Hamburg, Germany), which was dissolved in DMSO (Carl Roth, Karlsruhe, Germany) and diluted to the indicated concentrations.

\section{Annexin-V-binding and forward scatter}

After incubation under the respective experimental condition, $150 \mu \mathrm{l}$ cell suspension was washed in Ringer solution containing $5 \mathrm{mM} \mathrm{CaCl}_{2}$ and then stained with Annexin-V-FITC (1:200 dilution; ImmunoTools, Friesoythe, Germany) in this solution at $37^{\circ} \mathrm{C}$ for 20 min under protection from light. Then annexin- $\mathrm{V}$ fluorescence intensity was measured with an excitation wavelength of $488 \mathrm{~nm}$ and an emission wavelength of $530 \mathrm{~nm}$ on a FACS Calibur (BD, Heidelberg, Germany). In addition, the forward scatter (FSC) of the cells was determined, which reflects cell volume but does not allow safe quantitative statements on percentage cell volume change.

Reactive oxidant species (ROS)

Oxidative stress was determined utilizing 2',7'-dichlorodihydrofluorescein diacetate (DCFDA). After incubation, a $150 \mu \mathrm{l}$ suspension of erythrocytes was washed in Ringer solution and then stained with DCFDA (Sigma, Schnelldorf, Germany) in Ringer solution containing DCFDA at a final concentration of 10 $\mu \mathrm{M}$. Erythrocytes were incubated at $37^{\circ} \mathrm{C}$ for $30 \mathrm{~min}$ in the dark and then washed three times in Ringer solution. The DCFDA-loaded erythrocytes were resuspended in $200 \mu$ l Ringer solution, and ROS-dependent 
fluorescence intensity was measured at an excitation wavelength of $488 \mathrm{~nm}$ and an emission wavelength of $530 \mathrm{~nm}$ on a FACS Calibur (BD).

Intracellular $\mathrm{Ca}^{2+}$

After incubation, $150 \mu \mathrm{l}$ cell suspension was washed in Ringer solution and then loaded with Fluo3/AM (Biotium, Hayward, USA) in Ringer solution containing $5 \mathrm{mM} \mathrm{CaCl}_{2}$ and $5 \mu \mathrm{M}$ Fluo-3/AM. The cells were incubated at $37^{\circ} \mathrm{C}$ for $30 \mathrm{~min}$ and washed twice in Ringer solution containing $5 \mathrm{mM} \mathrm{CaCl} \mathrm{C}_{2}$. The Fluo-3/ AM-loaded erythrocytes were resuspended in $200 \mu \mathrm{l}$ Ringer. Then, $\mathrm{Ca}^{2+}$-dependent fluorescence intensity was measured with an excitation wavelength of $488 \mathrm{~nm}$ and an emission wavelength of $530 \mathrm{~nm}$ on a FACS Calibur.

\section{Determination of ceramide abundance at the erythrocyte surface}

To determine ceramide abundance, a monoclonal antibody-based assay was used. After incubation, cells were stained for $1 \mathrm{~h}$ at $37^{\circ} \mathrm{C}$ with $1 \mu \mathrm{g} / \mathrm{ml}$ anti-ceramide antibody (clone MID 15B4; Alexis, Grünberg, Germany) in phosphate-buffered saline (PBS) containing $0.1 \%$ bovine serum albumin (BSA) at a dilution of 1:10. After two washing steps with PBS-BSA, cells were stained for 30 min with polyclonal fluoresceinisothiocyanate (FITC)-conjugated goat anti-mouse IgG and IgM specific antibody (Pharmingen, Hamburg, Germany) diluted 1:50 in PBS-BSA. Unbound secondary antibody was removed by repeated washing with PBS-BSA. Samples were then analyzed by flow cytometric analysis at an excitation wavelength of $488 \mathrm{~nm}$ and an emission wavelength of $530 \mathrm{~nm}$.

\section{Statistics}

Data are expressed as arithmetic means \pm SEM. As indicated in the figure legends, statistical analysis was made using ANOVA with Tukey's test as post-test and $t$ test as appropriate. $\mathrm{n}$ denotes the number of different erythrocyte specimens studied. Since different erythrocyte specimens used in distinct experiments are differently susceptible to triggers of eryptosis, the same erythrocyte specimens have been used for control and experimental conditions.

\section{Results}

The present study explored whether mefloquine triggers eryptosis, the suicidal erythrocyte death. The hallmarks of eryptosis are phospholipid scambling of the cell membrane and cell shrinkage.

Phospholipid scambling of the cell membrane leads to phosphatidylserine translocation to the cell surface, which could be visualized with phosphatidylserine-binding FITClabelled annexin-V. Annexin-V-binding was quantified utilizing flow cytometry. Prior to flow cytometry, the erythrocytes were incubated for 48 hours in Ringer solution without or with presence of mefloquine $(1.25-50 \mu \mathrm{g} / \mathrm{ml})$. As shown in Fig. 1, a $48 \mathrm{~h}$ exposure to mefloquine increased the percentage of annexin-V-binding erythrocytes, an effect reaching statistical significance at $5 \mu \mathrm{g} / \mathrm{ml}$ mefloquine concentration. Mefloquine treatment is thus followed by phospholipid scrambling of the erythrocyte membrane with subsequent translocation of phosphatidylserine to the cell surface. An extended dose-response curve is provided in Fig. $1 \mathrm{C}, \mathrm{D}$.

As cell shrinkage is the second hallmark of eryptosis, erythrocyte cell volume was estimated from forward scatter in flow cytometry. Prior to flow cytometry, the erythrocytes were incubated for 48 hours in Ringer solution without or with mefloquine $11.25-50 \mu \mathrm{g} /$ $\mathrm{ml}$ ). As illustrated in Fig. 2, a 48 hours mefloquine treatment was followed by a decrease of erythrocyte forward scatter, an effect reaching statistical significance at $5 \mu \mathrm{g} / \mathrm{ml}$ mefloquine concentration.

Mechanisms triggering eryptosis include oxidative stress. Thus, additional experiments were performed to test, whether mefloquine influences the formation of reactive oxygen species (ROS). To this end, ROS was quantified utilizing $2^{\prime}, 7^{\prime}$-dichlorodihydrofluorescein diacetate (DCFDA). As shown in Fig. 3, a 48 hours exposure to mefloquine $(1.25-10 \mu \mathrm{g} / \mathrm{ml})$ 


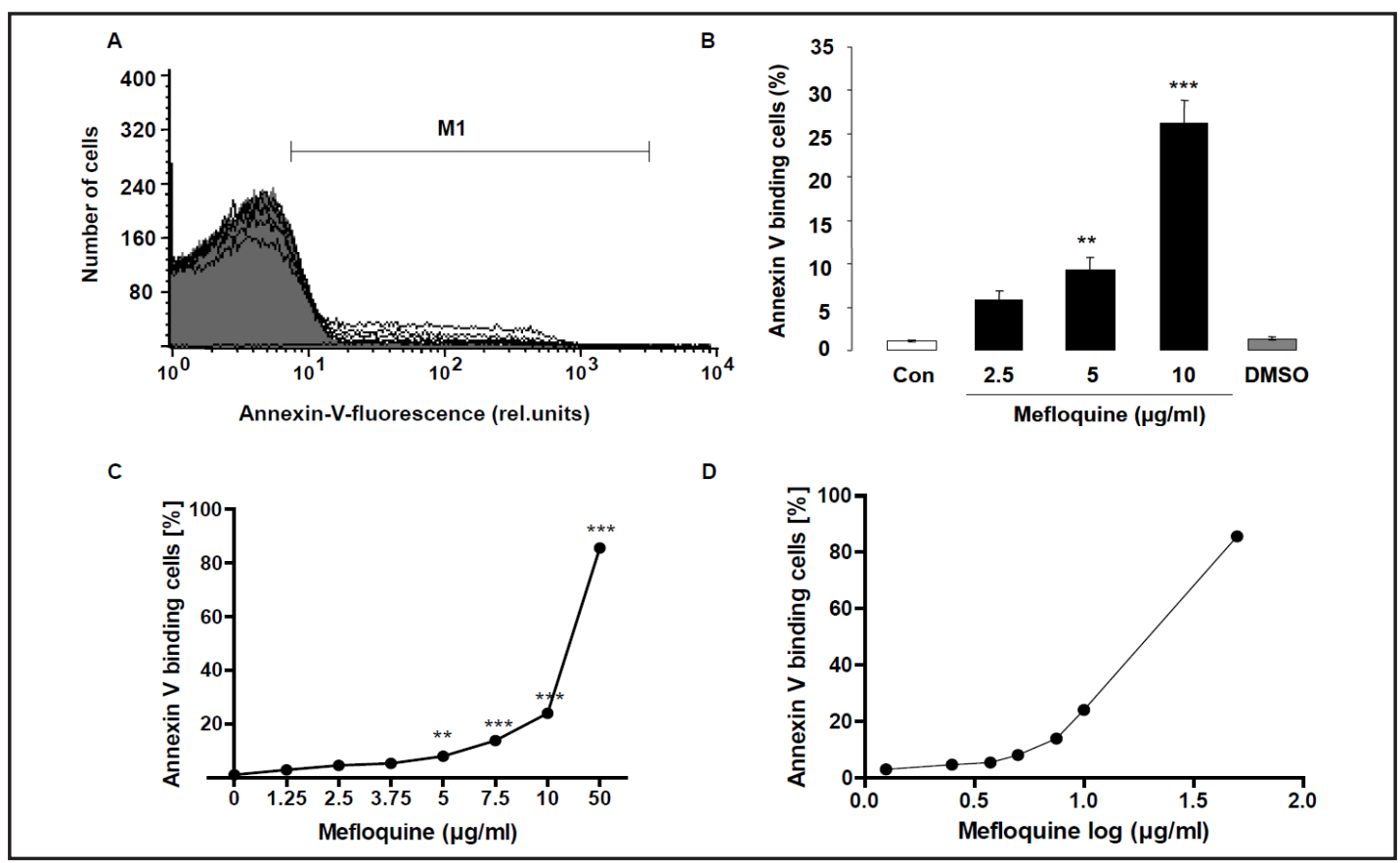

Fig. 1. Effect of mefloquine on phosphatidylserine exposure. A. Original histogram of annexin-V-binding of erythrocytes following exposure for $48 \mathrm{~h}$ to Ringer solution without (grey area) and with (black lines) presence of 1.25-50 $\mathrm{g} / \mathrm{ml}$ mefloquine. M1 indicates the annexin-V-fluoresence defining the percentage of annexin-V-binding erythrocytes. B. Arithmetic means \pm SEM of erythrocyte annexin-V-binding $(n=10)$ following incubation for $48 \mathrm{~h}$ to Ringer solution without (white bar) or with (black bars) presence of mefloquine $\left(2.5-10 \mu \mathrm{g} / \mathrm{ml} .{ }^{* *}(P<0.01),{ }^{* * *}(P<0.001)\right.$ indicate significant difference from the absence of mefloquine (ANOVA). C, D. Percentage of annexin V binding erythrocytes (\%) as a linear (C) and semilogarithmic (D) function of mefloquine concentration $(\mathrm{n}=15) .{ }^{* *}(P<0.01),{ }^{* * *}(P<0.001)$ indicate significant difference from the absence of mefloquine (ANOVA).

Fig. 2. Effect of mefloquine on erythrocyte forward scatter. A. Original histogram of forward scatter of erythrocytes following exposure for $48 \mathrm{~h}$ to Ringer solution without (grey area) and with (black lines) presence of 1.25-50 $\mu \mathrm{g} /$ $\mathrm{ml}$ mefloquine. B. Arithmetic means \pm SEM $(n=10)$ of the erythrocyte forward scatter (FSC) following incubation for 48 $\mathrm{h}$ to Ringer solution without (white bar)

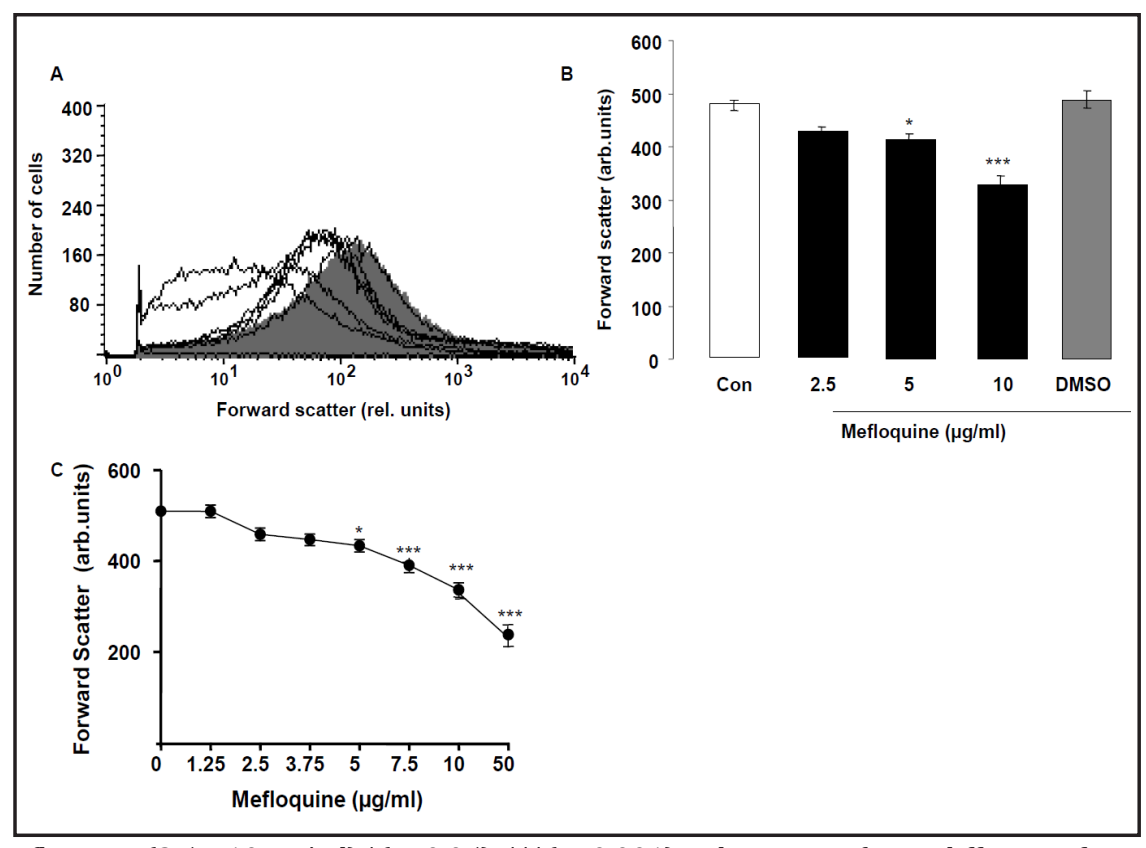
or with (black bars) mefloquine $(2.5-10 \mu \mathrm{g} / \mathrm{ml}) \cdot{ }^{*}(P<0.05),{ }^{* * *}(P<0.001)$ indicate significant difference from the absence of mefloquine (ANOVA). C. Erythrocyte forward scatter as a function of mefloquine concentration $(\mathrm{n}=15){ }^{*}(P<0.05),{ }^{* * *}(P<0.001)$ indicate significant difference from the absence of mefloquine (ANOVA). 


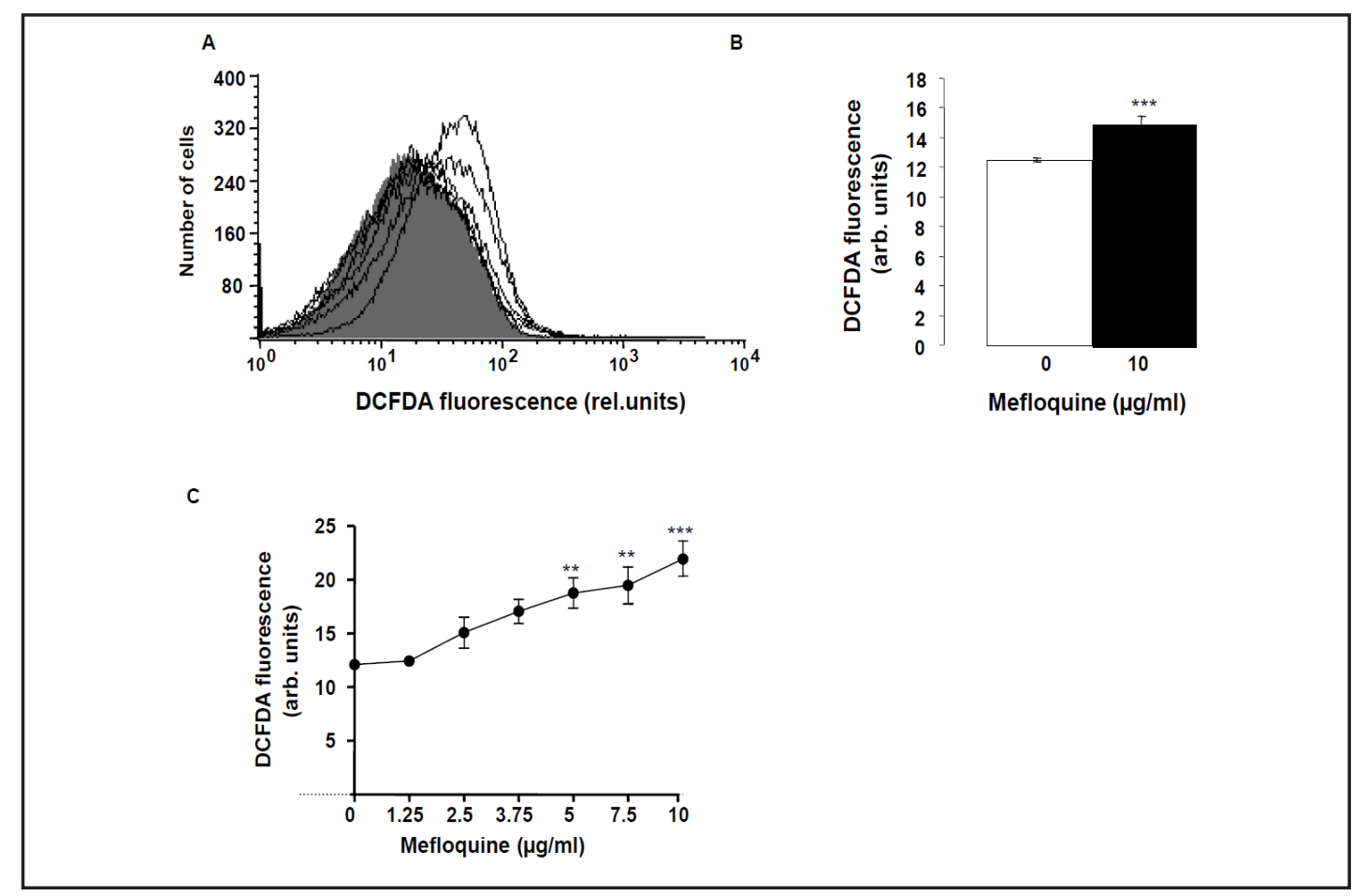

Fig. 3. Effect of mefloquine on reactive oxygen species. A. Original histogram of $2^{\prime}, 7^{\prime}$-dichlorodihydrofluorescein diacetate (DCFDA) fluorescence in erythrocytes following exposure for $48 \mathrm{~h}$ to Ringer solution without (grey shadow) and with (black lines) presence of 1.25-10 $\mu \mathrm{g} / \mathrm{ml}$ mefloquine. B. Arithmetic means \pm SEM (n $=4$ ) of the erythrocyte DCFDA fluorescence following incubation for $48 \mathrm{~h}$ to Ringer solution without (white bar) or with (black bar) presence of $10 \mu \mathrm{g} / \mathrm{ml}$ mefloquine. ${ }^{* * *}(P<0.001)$ indicates significant difference from the absence of mefloquine ( $t$ test). C. DCFDA fluorescence as a linear function of mefloquine concentration $(\mathrm{n}=9) .{ }^{* *}(P<0.01),{ }^{* * *}(P<0.001)$ indicate significant difference from the absence of mefloquine (ANOVA).

was followed by an increase of DCFDA fluorescence, an effect reaching statistical significance at $5 \mu \mathrm{g} / \mathrm{ml}$ mefloquine concentration. Accordingly, mefloquine induces oxidative stress.

Oxidative stress may open $\mathrm{Ca}^{2+}$ permeable cation channels with subsequent $\mathrm{Ca}^{2+}$ entry. Additional experiments were thus performed exploring whether mefloquine influences cytosolic $\mathrm{Ca}^{2+}$ activity $\left(\left[\mathrm{Ca}^{2+}\right]_{i}\right)$. Fluo3 fluorescence was employed to quantify $\left[\mathrm{Ca}^{2+}\right]_{\mathrm{i}^{\prime}}$ As shown in Fig. 4, a $48 \mathrm{~h}$ exposure to mefloquine $(1.25-10 \mu \mathrm{g} / \mathrm{ml})$ increased Fluo3 fluorescence reflecting increase of $\left[\mathrm{Ca}^{2+}\right]_{i}$, an effect reaching statistical significance at $7.5 \mu \mathrm{g} / \mathrm{ml}$ mefloquine concentration. An additional series of experiments was performed in order to test whether mefloquine-induced translocation of phosphatidylserine to the cell surface required entry of extracellular $\mathrm{Ca}^{2+}$. To this end, erythrocytes were incubated for 48 hours in the absence or presence of $10 \mu \mathrm{g} / \mathrm{ml}$ mefloquine, both in the presence or nominal absence of extracellular $\mathrm{Ca}^{2+}$. As shown in Fig. 4E, removal of extracellular $\mathrm{Ca}^{2+}$ significantly blunted the effect of mefloquine on annexin-V-binding, an observation indicating that entry of extracellular $\mathrm{Ca}^{2+}$ contributed to the stimulation of cell membrane scrambling by mefloquine. However, even in the absence of extracellular $\mathrm{Ca}^{2+}$, mefloquine significantly increased the percentage of annexin-V-binding erythrocytes, indicating that eryptosis was in part due to mechanisms other than entry of extracellular $\mathrm{Ca}^{2+}$.

Mechanisms stimulating cell membrane scrambling even without $\mathrm{Ca}^{2+}$ entry and subsequent increase of $\left[\mathrm{Ca}^{2+}\right]_{\mathrm{i}}$ include ceramide. Accordingly, the ceramide abundance at the erythrocyte surface was determined utilizing a specific anti-ceramide antibody. As shown in Fig. 5, exposing erythrocytes for 48 hours to $1.25-10 \mu \mathrm{g} / \mathrm{ml}$ mefloquine was followed by an increase of the ceramide abundance at the erythrocyte surface, an effect reaching statistical significance at $10 \mu \mathrm{g} / \mathrm{ml}$ mefloquine concentration. 


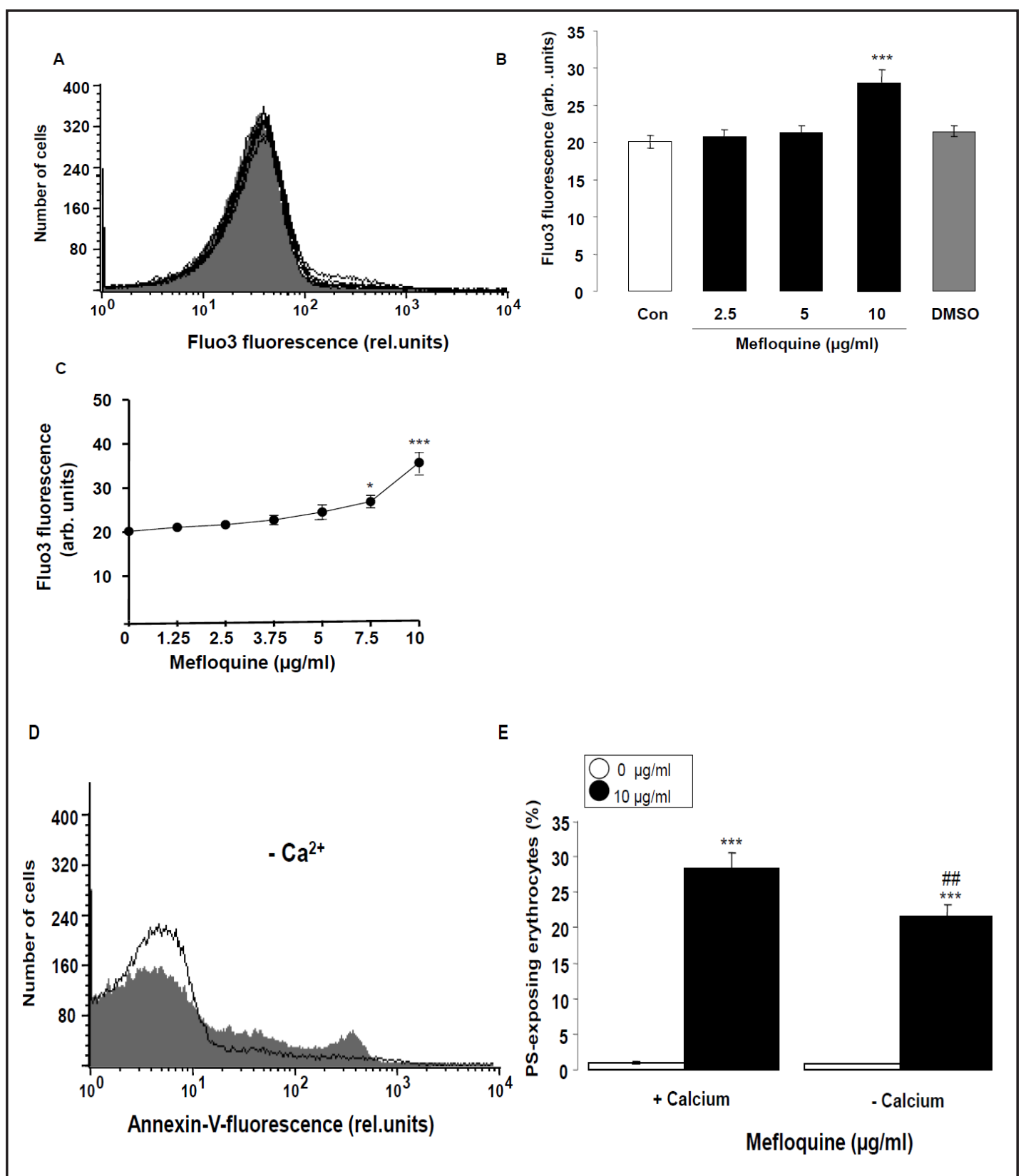

Fig. 4. Effect of mefloquine on erythrocyte $\mathrm{Ca}^{2+}$ activity and $\mathrm{Ca}^{2+}$ dependence of mefloquine- induced phosphatidylserine exposure. A. Original histogram of Fluo3 fluorescence in erythrocytes following exposure for $48 \mathrm{~h}$ to Ringer solution without (grey area) and with (black lines) presence of $1.25-10 \mu \mathrm{g} / \mathrm{ml}$ mefloquine. B. Arithmetic means \pm SEM ( $\mathrm{n}=10$ ) of the Fluo3 fluorescence (arbitrary units) in erythrocytes exposed for 48 $\mathrm{h}$ to Ringer solution without (white bar) or with (black bars) mefloquine $(1.25-10 \mu \mathrm{g} / \mathrm{ml}) .{ }^{* * *}(P<0.001)$ indicates significant difference from the absence of mefloquine (ANOVA). C. Fluo3 fluorescence as a function of mefloquine concentration $(\mathrm{n}=15) .{ }^{*}(P<0.05),{ }^{* * *}(P<0.001)$ indicate significant difference from the absence of mefloquine (ANOVA). D. Original histogram of annexin $V$ binding of erythrocytes following exposure for $48 \mathrm{~h}$ to Ringer solution in the absence of calcium, without (grey area) and with (black line) presence of 10 $\mu \mathrm{g} / \mathrm{ml}$ mefloquine. E. Arithmetic means \pm SEM $(\mathrm{n}=8)$ of erythrocyte annexin-V-binding after a $48 \mathrm{~h}$ treatment with Ringer solution without (white bars) or with (black bars) $10 \mu \mathrm{g} / \mathrm{ml}$ mefloquine in the presence (left bars, +Calcium) and absence (right bars, -Calcium) of $\mathrm{Ca}^{2+} . * * *(P<0.001)$ indicates significant difference from the absence of mefloquine, $\# \#(P<0.01)$ indicates significant difference from the respective value in the presence of $\mathrm{Ca}^{2+}$. 


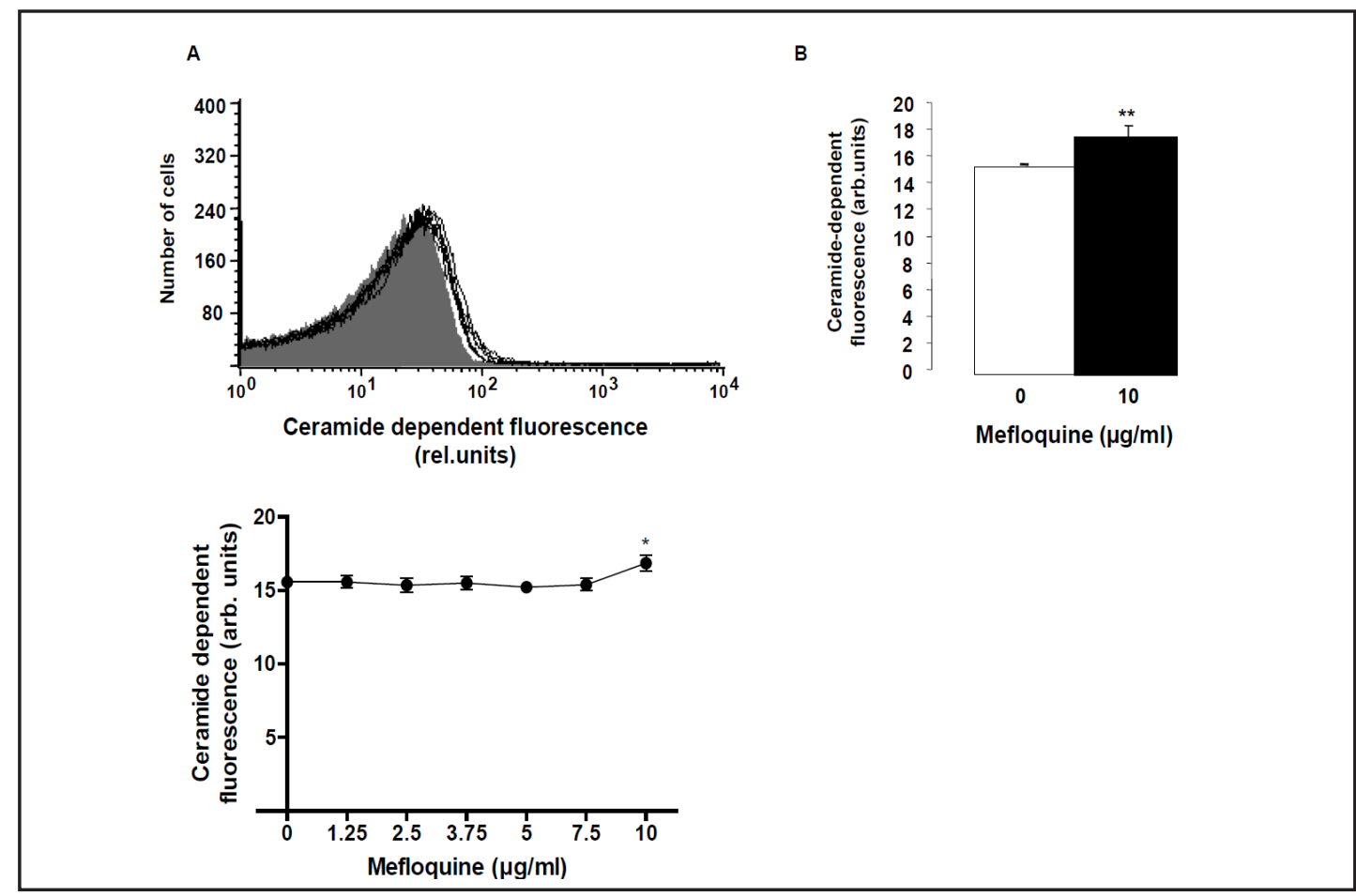

Fig. 5. Effect of mefloquine on ceramide abundance. A. Original histogram of ceramide abundance at the erythrocyte surface following exposure for $48 \mathrm{~h}$ to Ringer solution without (grey shadow) and with (black lines) presence of $1.25-10 \mu \mathrm{g} / \mathrm{ml}$ mefloquine. B. Arithmetic means \pm SEM $(\mathrm{n}=4)$ of ceramide abundance after a $48 \mathrm{~h}$ incubation in Ringer solution without (white bar) or with $10 \mu \mathrm{g} / \mathrm{ml}$ mefloquine (black bar). ** $(P<0.01)$ indicates significant difference from the absence of mefloquine $(t$ test). C. Ceramide abundance as a function of mefloquine concentration $(n=10) .{ }^{*}(P<0.05)$ indicates significant difference from the absence of mefloquine (ANOVA).

\section{Discussion}

The present observations unravel a novel effect of mefloquine, i.e. the triggering of cell shrinkage and erythrocyte cell membrane scrambling with phosphatidylserine translocation from the cell interior to the erythrocyte surface. Cell shrinkage and cell membrane scrambling are the hallmarks of eryptosis, the suicidal erythrocyte death. The mefloquine concentration required for stimulation of erythrocyte cell membrane scrambling is similar (forward scatter) or slightly higher (annexin-V-binding) than the plasma concentrations $(2.5 \mu \mathrm{g} / \mathrm{ml})$ reported in vivo [66]. The observations are at variance to an earlier paper failing to observe an effect of mefloquine on phosphatidylserine abundance at the erythrocyte surface [67].

The mefloquine induced erythrocyte shrinkage was paralleled by and is at least partially due to increase of cytosolic $\mathrm{Ca}^{2+}$ activity $\left(\left[\mathrm{Ca}^{2+}\right]_{\mathrm{i}}\right)$, which activates $\mathrm{Ca}^{2+}$ sensitive $\mathrm{K}^{+}$channels leading to $\mathrm{K}^{+}$exit, cell membrane hyperpolarization, $\mathrm{Cl}^{-}$exit and thus cellular loss of $\mathrm{KCl}$ with osmotically obliged water [24].

The increase of $\left[\mathrm{Ca}^{2+}\right]_{\mathrm{i}}$ may have been due to oxidative stress, which activates oxidant sensitive $\mathrm{Ca}^{2+}$ permeable erythrocytic cation channels [25], thus contributing to mefloquine induced $\mathrm{Ca}^{2+}$ entry. Mefloquine has similarly been reported to induce oxidative stress in nucleated cells $[10,18,21]$.

Removal of extracellular $\mathrm{Ca}^{2+}$ significantly blunted the stimulation of annexin-V-binding following mefloquine treatment, indicating that $\mathrm{Ca}^{2+}$ entry contributes to the stimulation of mefloquine induced cell membrane scrambling. However, mefloquine enhanced the phosphatidylserine abundance at the cell surface significantly even in the absence of extracellular $\mathrm{Ca}^{2+}$. Thus, the effect of mefloquine on $\mathrm{Ca}^{2+}$ entry contributed to, but did not fully 
account for the triggering of cell membrane scrambling. Accordingly, mefloquine triggered cell membrane scrambling through additional, $\mathrm{Ca}^{2+}$ independent mechanisms.

Mechanisms triggering cell membrane scrambling even at constant $\left[\mathrm{Ca}^{2+}\right]_{\mathrm{i}}$ include ceramide [25]. Mefloquine treatment indeed enhanced the ceramide abundance in the erythrocyte cell membrane. The increase could result from either, formation of new ceramide or translocation of preexisting ceramide to the erythrocyte surface. Mefloquine has previously been shown to increase ceramide formation in nucleated cells [22].

The physiological purpose of eryptosis is the disposal of defective erythrocytes and thus avoidance of hemolysis [25]. Hemolysis leads to release of hemoglobin, which may be filtered in the kidney and precipitate in the acidic lumen of renal tubules thus occluding affected nephrons [68]. Eryptosis may further lead to removal of infected erythrocytes during malaria [23]. The malaria pathogen Plasmodium imposes oxidative stress on the host erythrocyte, which in turn activates several host cell ion channels including $\mathrm{Ca}^{2+}$-permeable erythrocyte cation channels $[25,69]$. The $\mathrm{Ca}^{2+}$ entry through those channels eventually leads to cell membrane scrambling of the infected erythrocytes with phosphatidylserine dependent phagocytosis and thus clearance from circulating blood [23]. The removal of infected phosphatidylserine exposing erythrocytes lowers the parasitemia and thus favourably influences the clinical course of malaria. Along those lines, enhanced erythrocyte susceptibility to triggers of eryptosis may protect carriers of several genetic erythrocyte disorders, such as sickle-cell trait, beta-thalassemia-trait, homozygous Hb-C and homozygous G6PD-deficiency, against a severe course of malaria [25, 70-72]. Stimulated eryptosis may further contribute to the protective effect against malaria of iron deficiency [73], lead intoxication [73], treatment with chlorpromazine [74] or presence of NO synthase inhibitors [74]. It is tempting to speculate that the antimalarial effect of mefloquine could be in part due to stimulation of eryptosis. Needless to say that additional experimentation would be required to confirm or falsify this speculation.

In conclusion, mefloquine stimulates erythrocyte cell membrane scrambling, an effect paralleled by and at least partially resulting from induction of oxidative stress, increase of cytosolic $\mathrm{Ca}^{2+}$ activity and enhanced ceramide abundance at the erythrocyte surface.

\section{Acknowledgements}

The authors acknowledge the meticulous preparation of the manuscript by Tanja Loch. The study was supported by the Deutsche Forschungsgemeinschaft and Open Access Publishing Fund of Tuebingen University.

\section{Disclosure Statement}

No conflict of interest.

\section{References}

1 Bukirwa H, Orton L: Artesunate plus mefloquine versus mefloquine for treating uncomplicated malaria. Cochrane Database Syst Rev 2005;10.1002/14651858.CD004531.pub2CD004531.

$\checkmark 2$ Cayley WE, Jr.: Mefloquine for preventing malaria in nonimmune adult travelers. Am Fam Physician 2004;69:521-522.

-3 Croft AM, Garner P: Mefloquine for preventing malaria in non-immune adult travellers. Cochrane Database Syst Rev 2000;10.1002/14651858.CD000138CD000138.

4 Croft AM, Garner P: WITHDRAWN: Mefloquine for preventing malaria in non-immune adult travellers. Cochrane Database Syst Rev 2008;10.1002/14651858.CD000138.pub2CD000138. 


\section{Cellular Physiology Cell Physiol Biochem 2015;36:1395-1405 \begin{tabular}{l|l|l} 
and Biochemistry & $\begin{array}{l}\text { DOI: 10.1159/000430305 } \\
\text { Publisned onlne: July v1, } 2015\end{array}$ & $\begin{array}{l}\text { O) 2015 S. Karger AG, Basel } \\
\text { www.karger.com/cpb }\end{array}$ \\
\cline { 2 - 3 }
\end{tabular}}

5 Gonzalez R, Hellgren U, Greenwood B, Menendez C: Mefloquine safety and tolerability in pregnancy: a systematic literature review. Malar J 2014;13:75.

6 Schlagenhauf P, Adamcova M, Regep L, Schaerer MT, Bansod S, Rhein HG: Use of mefloquine in children - a review of dosage, pharmacokinetics and tolerability data. Malar J 2011;10:292.

7 Schlagenhauf P, Adamcova M, Regep L, Schaerer MT, Rhein HG: The position of mefloquine as a 21st century malaria chemoprophylaxis. Malar J 2010;9:357.

-8 Wongsrichanalai C, Prajakwong S, Meshnick SR, Shanks GD, Thimasarn K: Mefloquine--its 20 years in the Thai Malaria Control Program. Southeast Asian J Trop Med Public Health 2004;35:300-308.

-9 Xiao SH: Mefloquine, a new type of compound against schistosomes and other helminthes in experimental studies. Parasitol Res 2013;112:3723-3740.

10 Milatovic D, Jenkins JW, Hood JE, Yu Y, Rongzhu L, Aschner M: Mefloquine neurotoxicity is mediated by nonreceptor tyrosine kinase. Neurotoxicology 2011;32:578-585.

11 Naing C, Aung K, Ahmed SI, Mak JW: Signal detection to identify serious adverse events (neuropsychiatric events) in travelers taking mefloquine for chemoprophylaxis of malaria. Drug Healthc Patient Saf 2012;4:87-92.

12 Toovey S: Mefloquine neurotoxicity: a literature review. Travel Med Infect Dis 2009;7:2-6.

13 Young BE, Yeo TR, Lim HT, Vong KY, Tan K, Lye DC, Lee CC: Progressive Multifocal Leukoencephalopathy with Immune Reconstitution Inflammatory Syndrome (PML-IRIS): two case reports of successful treatment with mefloquine and a review of the literature. Ann Acad Med Singapore 2012;41:620-624.

14 Yu D, Ding D, Jiang H, Stolzberg D, Salvi R: Mefloquine damage vestibular hair cells in organotypic cultures. Neurotox Res 2011;20:51-58.

15 Smith HR, Croft AM, Black MM: Dermatological adverse effects with the antimalarial drug mefloquine: a review of 74 published case reports. Clin Exp Dermatol 1999;24:249-254.

-16 Nevin RL: Mefloquine gap junction blockade and risk of pregnancy loss. Biol Reprod 2012;87:65.

17 Das S, Lin D, Jena S, Shi A, Battina S, Hua DH, Allbaugh R, Takemoto DJ: Protection of retinal cells from ischemia by a novel gap junction inhibitor. Biochem Biophys Res Commun 2008;373:504-508.

18 Ding D, Qi W, Yu D, Jiang H, Han C, Kim MJ, Katsuno K, Hsieh YH, Miyakawa T, Salvi R, Tanokura M, Someya S: Addition of exogenous NAD+ prevents mefloquine-induced neuroaxonal and hair cell degeneration through reduction of caspase-3-mediated apoptosis in cochlear organotypic cultures. PLoS One 2013;8:e79817.

19 Geng Y, Kohli L, Klocke BJ, Roth KA: Chloroquine-induced autophagic vacuole accumulation and cell death in glioma cells is p53 independent. Neuro Oncol 2010;12:473-481.

20 Kim JH, Choi AR, Kim YK, Yoon S: Co-treatment with the anti-malarial drugs mefloquine and primaquine highly sensitizes drug-resistant cancer cells by increasing P-gp inhibition. Biochem Biophys Res Commun 2013;441:655-660.

21 Yadav N, Dwivedi A, Mujtaba SF, Verma A, Chaturvedi R, Ray RS, Singh G: Photosensitized mefloquine induces ROS-mediated DNA damage and apoptosis in keratinocytes under ambient UVB and sunlight exposure. Cell Biol Toxicol 2014;30:253-268.

22 Pankova-Kholmyansky I, Dagan A, Gold D, Zaslavsky Z, Skutelsky E, Gatt S, Flescher E: Ceramide mediates growth inhibition of the Plasmodium falciparum parasite. Cell Mol Life Sci 2003;60:577-587.

23 Foller M, Bobbala D, Koka S, Huber SM, Gulbins E, Lang F: Suicide for survival--death of infected erythrocytes as a host mechanism to survive malaria. Cell Physiol Biochem 2009;24:133-140.

24 Lang PA, Kaiser S, Myssina S, Wieder T, Lang F, Huber SM: Role of Ca2+-activated K+ channels in human erythrocyte apoptosis. Am J Physiol Cell Physiol 2003;285:C1553-C1560.

25 Lang E, Qadri SM, Lang F: Killing me softly - suicidal erythrocyte death. Int J Biochem Cell Biol 2012;44:1236-1243.

26 Abed M, Towhid ST, Mia S, Pakladok T, Alesutan I, Borst O, Gawaz M, Gulbins E, Lang F: Sphingomyelinaseinduced adhesion of eryptotic erythrocytes to endothelial cells. Am J Physiol Cell Physiol 2012;303:C991999.

27 Lau IP, Chen H, Wang J, Ong HC, Leung KC, Ho HP, Kong SK: In vitro effect of CTAB- and PEG-coated gold nanorods on the induction of eryptosis/erythroptosis in human erythrocytes. Nanotoxicology 2012;6:847856.

28 Maellaro E, Leoncini S, Moretti D, Del Bello B, Tanganelli I, De Felice C, Ciccoli L: Erythrocyte caspase-3 activation and oxidative imbalance in erythrocytes and in plasma of type 2 diabetic patients. Acta Diabetol 2013;50:489-495. 


\section{Cellular Physiology Cell Physiol Biochem 2015;36:1395-1405 \begin{tabular}{l|l} 
and Biochemistry Publisnea onIIne: July U1, 2015 & $\begin{array}{l}\text { C } 2015 \text { S. Karger AG, Basel } \\
\text { www.karger.com/cpb }\end{array}$ \\
\hline
\end{tabular}

29 Jilani K, Qadri SM, Lang F: Geldanamycin-induced phosphatidylserine translocation in the erythrocyte membrane. Cell Physiol Biochem 2013;32:1600-1609.

-30 Polak-Jonkisz D, Purzyc L: Ca Influx versus Efflux during Eryptosis in Uremic Erythrocytes. Blood Purif 2012;34:209-210.

31 Qian EW, Ge DT, Kong SK: Salidroside protects human erythrocytes against hydrogen peroxide-induced apoptosis. J Nat Prod 2012;75:531-537.

-32 Vota DM, Maltaneri RE, Wenker SD, Nesse AB, Vittori DC: Differential erythropoietin action upon cells induced to eryptosis by different agents. Cell Biochem Biophys 2013;65:145-157.

-33 Weiss E, Cytlak UM, Rees DC, Osei A, Gibson JS: Deoxygenation-induced and $\mathrm{Ca}(2+)$ dependent phosphatidylserine externalisation in red blood cells from normal individuals and sickle cell patients. Cell Calcium 2012;51:51-56.

34 Zbidah M, Lupescu A, Jilani K, Lang F: Stimulation of suicidal erythrocyte death by fumagillin. Basic Clin Pharmacol Toxicol 2013;112:346-351.

-35 Abed M, Herrmann T, Alzoubi K, Pakladok T, Lang F: Tannic Acid induced suicidal erythrocyte death. Cell Physiol Biochem 2013;32:1106-1116.

-36 Ahmed MS, Langer H, Abed M, Voelkl J, Lang F: The uremic toxin acrolein promotes suicidal erythrocyte death. Kidney Blood Press Res 2013;37:158-167.

37 Ghashghaeinia M, Cluitmans JC, Toulany M, Saki M, Koberle M, Lang E, Dreischer P, Biedermann T, Duszenko M, Lang F, Bosman GJ, Wieder T: Age Sensitivity of NFkappaB Abundance and Programmed Cell Death in Erythrocytes Induced by NFkappaB Inhibitors. Cell Physiol Biochem 2013;32:801-813.

38 Alzoubi K, Honisch S, Abed M, Lang F: Triggering of Suicidal Erythrocyte Death by Penta-O-galloyl-beta-dglucose. Toxins (Basel) 2014;6:54-65.

-39 Lupescu A, Bissinger R, Jilani K, Lang F: Triggering of suicidal erythrocyte death by celecoxib. Toxins (Basel) 2013;5:1543-1554.

40 Lupescu A, Jilani K, Zbidah M, Lang F: Patulin-induced suicidal erythrocyte death. Cell Physiol Biochem 2013;32:291-299.

41 Abed M, Zoubi KA, Theurer M, Lang F: Effect of dermaseptin on erythrocytes. Basic Clin Pharmacol Toxicol 2013;113:347-352.

42 Arnold M, Lang E, Modicano P, Bissinger R, Faggio C, Abed M, Lang F: Effect of nitazoxanide on erythrocytes. Basic Clin Pharmacol Toxicol 2014;114:421-426.

43 Oswald G, Alzoubi K, Abed M, Lang F: Stimulation of suicidal erythrocyte death by ribavirin. Basic Clin Pharmacol Toxicol 2014;114:311-317.

44 Bissinger R, Malik A, Jilani K, Lang F: Triggering of Erythrocyte Cell Membrane Scrambling by Salinomycin. Basic Clin Pharmacol Toxicol 2014;10.1111/bcpt.12250

45 Jacobi J, Lang E, Bissinger R, Frauenfeld L, Modicano P, Faggio C, Abed M, Lang F: Stimulation of erythrocyte cell membrane scrambling by mitotane. Cell Physiol Biochem 2014;33:1516-1526.

-46 Lupescu A, Bissinger R, Herrmann T, Oswald G, Jilani K, Lang F: Induction of suicidal erythrocyte death by novobiocin. Cell Physiol Biochem 2014;33:670-680.

47 Lupescu A, Bissinger R, Warsi J, Jilani K, Lang F: Stimulation of erythrocyte cell membrane scrambling by gedunin. Cell Physiol Biochem 2014;33:1838-1848.

48 Abed M, Feger M, Alzoubi K, Pakladok T, Frauenfeld L, Geiger C, Towhid ST, Lang F: Sensitization of erythrocytes to suicidal erythrocyte death following water deprivation. Kidney Blood Press Res 2013;37:567-578.

49 Alzoubi K, Calabro S, Bissinger R, Abed M, Faggio C, Lang F: Stimulation of suicidal erythrocyte death by artesunate. Cell Physiol Biochem 2014;34:2232-2244.

50 Arnold M, Bissinger R, Lang F: Mitoxantrone-induced suicidal erythrocyte death. Cell Physiol Biochem 2014;34:1756-1767.

51 Bissinger R, Fischer S, Jilani K, Lang F: Stimulation of erythrocyte death by phloretin. Cell Physiol Biochem 2014;34:2256-2265.

52 Bissinger R, Lupescu A, Zelenak C, Jilani K, Lang F: Stimulation of eryptosis by cryptotanshinone. Cell Physiol Biochem 2014;34:432-442.

53 Bissinger R, Modicano P, Frauenfeld L, Lang E, Jacobi J, Faggio C, Lang F: Estramustine-induced suicidal erythrocyte death. Cell Physiol Biochem 2013;32:1426-1436. 


\section{Cellular Physiology Cell Physiol Biochem 2015;36:1395-1405

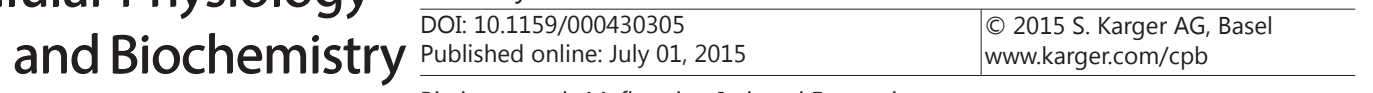

54 Malik A, Bissinger R, Calabro S, Faggio C, Jilani K, Lang F: Aristolochic acid induced suicidal erythrocyte death. Kidney Blood Press Res 2014;39:408-419.

55 Tesoriere L, Attanzio A, Allegra M, Cilla A, Gentile C, Livrea MA: Oxysterol mixture in hypercholesterolemiarelevant proportion causes oxidative stress-dependent eryptosis. Cell Physiol Biochem 2014;34:10751089.

-56 Voelkl J, Alzoubi K, Mamar AK, Ahmed MS, Abed M, Lang F: Stimulation of suicidal erythrocyte death by increased extracellular phosphate concentrations. Kidney Blood Press Res 2013;38:42-51.

57 Zhang R, Xiang Y, Ran Q, Deng X, Xiao Y, Xiang L, Li Z: Involvement of calcium, reactive oxygen species, and ATP in hexavalent chromium-induced damage in red blood cells. Cell Physiol Biochem 2014;34:1780-1791.

-58 Borst 0, Abed M, Alesutan I, Towhid ST, Qadri SM, Foller M, Gawaz M, Lang F: Dynamic adhesion of eryptotic erythrocytes to endothelial cells via CXCL16/SR-PSOX. Am J Physiol Cell Physiol 2012;302:C644-C651.

59 Andrews DA, Low PS: Role of red blood cells in thrombosis. Curr Opin Hematol 1999;6:76-82.

60 Chung SM, Bae ON, Lim KM, Noh JY, Lee MY, Jung YS, Chung JH: Lysophosphatidic acid induces thrombogenic activity through phosphatidylserine exposure and procoagulant microvesicle generation in human erythrocytes. Arterioscler Thromb Vasc Biol 2007;27:414-421.

61 Zwaal RF, Comfurius P, Bevers EM: Surface exposure of phosphatidylserine in pathological cells. Cell Mol Life Sci 2005;62:971-988.

62 Closse C, Dachary-Prigent J, Boisseau MR: Phosphatidylserine-related adhesion of human erythrocytes to vascular endothelium. Br J Haematol 1999;107:300-302.

63 Gallagher PG, Chang SH, Rettig MP, Neely JE, Hillery CA, Smith BD, Low PS: Altered erythrocyte endothelial adherence and membrane phospholipid asymmetry in hereditary hydrocytosis. Blood 2003;101:46254627.

64 Pandolfi A, Di Pietro N, Sirolli V, Giardinelli A, Di Silvestre S, Amoroso L, Di Tomo P, Capani F, Consoli A, Bonomini M: Mechanisms of uremic erythrocyte-induced adhesion of human monocytes to cultured endothelial cells. J Cell Physiol 2007;213:699-709.

65 Wood BL, Gibson DF, Tait JF: Increased erythrocyte phosphatidylserine exposure in sickle cell disease: flowcytometric measurement and clinical associations. Blood 1996;88:1873-1880.

66 Boudreau EF, Fleckenstein L, Pang LW, Childs GE, Schroeder AC, Ratnaratorn B, Phintuyothin P: Mefloquine kinetics in cured and recrudescent patients with acute falciparum malaria and in healthy volunteers. Clin Pharmacol Ther 1990;48:399-409.

67 Totino PR, Daniel-Ribeiro CT, Ferreira-da-Cruz Mde F: Pro-apoptotic effects of antimalarial drugs do not affect mature human erythrocytes. Acta Trop 2009;112:236-238.

68 Harrison HE, Bunting H, Ordway NK, Albrink WS: The Pathogenesis of the Renal Injury Produced in the Dog by Hemoglobin or Methemoglobin. J Exp Med 1947;86:339-356.

69 Kirk K: Membrane transport in the malaria-infected erythrocyte. Physiol Rev 2001;81:495-537.

70 Ayi K, Giribaldi G, Skorokhod A, Schwarzer E, Prendergast PT, Arese P: 16alpha-bromoepiandrosterone, an antimalarial analogue of the hormone dehydroepiandrosterone, enhances phagocytosis of ring stage parasitized erythrocytes: a novel mechanism for antimalarial activity. Antimicrob Agents Chemother 2002;46:3180-3184.

71 Ayi K, Turrini F, Piga A, Arese P: Enhanced phagocytosis of ring-parasitized mutant erythrocytes: a common mechanism that may explain protection against falciparum malaria in sickle trait and beta-thalassemia trait. Blood 2004;104:3364-3371.

72 Cappadoro M, Giribaldi G, O'Brien E, Turrini F, Mannu F, Ulliers D, Simula G, Luzzatto L, Arese P: Early phagocytosis of glucose-6-phosphate dehydrogenase (G6PD)-deficient erythrocytes parasitized by Plasmodium falciparum may explain malaria protection in G6PD deficiency. Blood 1998;92:2527-2534.

73 Koka S, Huber SM, Boini KM, Lang C, Foller M, Lang F: Lead decreases parasitemia and enhances survival of Plasmodium berghei-infected mice. Biochem Biophys Res Commun 2007;363:484-489.

74 Koka S, Lang C, Niemoeller OM, Boini KM, Nicolay JP, Huber SM, Lang F: Influence of NO synthase inhibitor L-NAME on parasitemia and survival of Plasmodium berghei infected mice. Cell Physiol Biochem 2008;21:481-488. 